\title{
Factors Affecting International and National Tourist Arrivals (1974-2020) in Leh District (U.T. Ladakh, India)
}

\author{
Vladimiro Pelliciardi ${ }^{1} \mathrm{PhD}$
}

\begin{abstract}
Since 1974, tourists are attracted in Leh district for its mountainous landscape, environment, high altitude lakes, Indus River, beautiful villages and Himalayan people living in scenography valleys filled of Buddhist heritage sites. All makes this region a great place for adventure sports, sightseen, cultural and religious tourism. Tourism industry has rapidly become one of the most important aspects of District development paths. Visitors bring hard currency and spend money contributing to monetary economic boom that can have both positive and negative impacts on the society and territory. Tourism in Leh District has a short season (from May to October) but a highly profitable business especially with national visitors increasing by the day. This study, based on data collected from the Tourism Department in Leh, analyses the international and national tourist arrivals in time series to find out pattern and trends in the historical data and investigate global and local factors affecting tourist inflows (rises or falls) in the District. Yearly arrivals depends on several factors and issues as geopolitical and global economic problems, new trends in tourist destinations, film induced tourism, climate changes, natural disasters, pandemic and more. These unpredictable factors affect tourist flows, decreasing or increasing the arrivals even drastically. The long-term sustainability of the local development must not depend mainly on mass tourism because economic dependence on only one, although promising but fluctuating sector, pose several problems (e.g. impacts and pressure on infrastructures, environment and significant socio-cultural changes.
\end{abstract}

Keywords: Tourism, Tourist arrivals, Leh District, Ladakh, Sustainable development.

\section{Introduction}

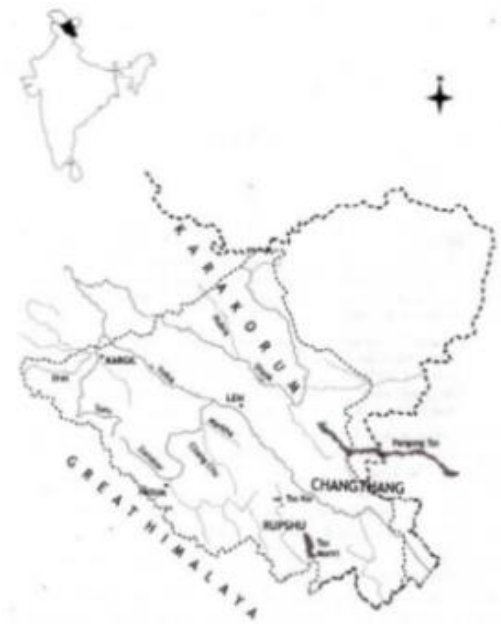

Figure 1: Ladakh map
Ladakh is a region of Indian Trans-Himalaya (Figure 1), for decades, a division of the Jammu and Kashmir State (in 2019, Ladakh become Union Territory of India), geographically classified as "high cold desert" (altitude ranging from 2,300 to 7,672 m.a.s.l.). Politically it is divided into two districts: Leh in the central and eastern parts (area: $45,110 \mathrm{~km}^{2}$; 147,104 inhabitants), and Kargil (area: 14,036 km²; 143,388 inhabitants), in the northwest. For many centuries, local population has led a self-reliant existence mainly based upon subsistence agriculture, pastoralism and caravan trade. After China-India war in 1962, the militarization of the area, the modernization due to governmental programs and the progressive opening to external influences and 
resources, such as tourism, have characterized the development paths (Rizvi 1996). Tourists are attracted in Leh district for its mountainous landscape (Figure 2), environment, high altitude lakes, Indus River, beautiful villages and Himalayan people living in scenography valleys, filled of Buddhist heritage sites. All makes this region a great place for adventure sports, sightseen, cultural and religious tourism, and for national, also "to escape from the heat and bumidity of Indian plains" (Pelliciardi 2010:15) during summer.

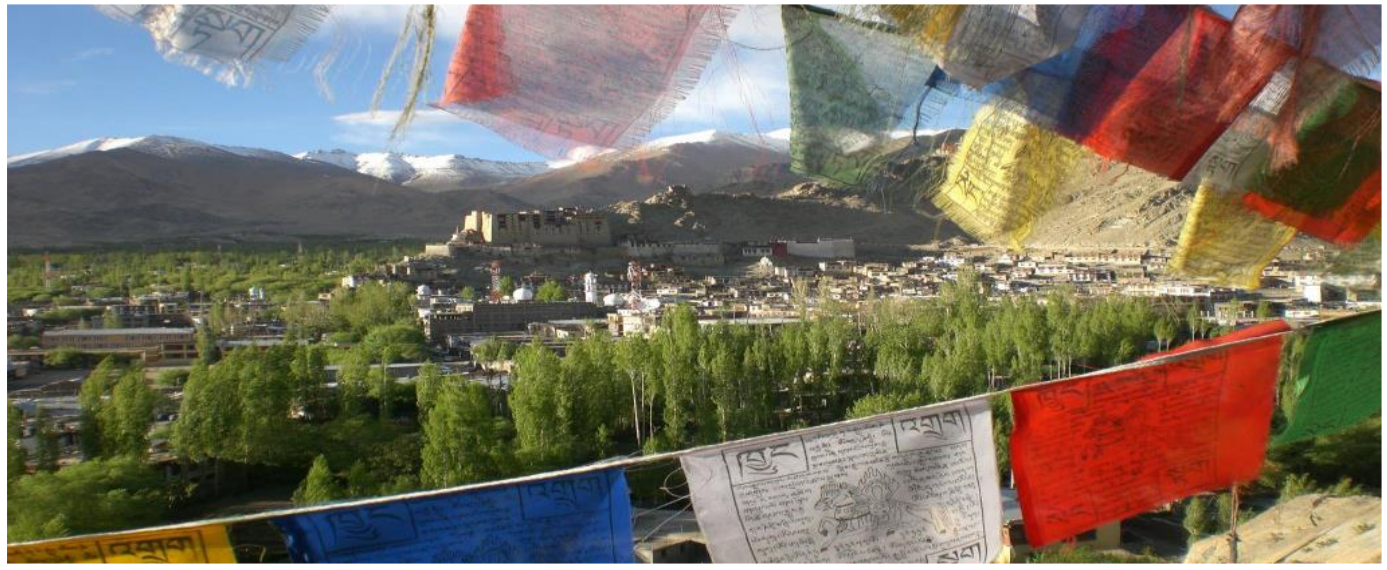

Figure 2: Leh valley and town.

Initiated in 1974, tourism in Leh district is today 47 years old. During this period, approximately 2,700,000 tourists have visited Leh district (population in 1971 around 53,000 and estimated 147,000 in 2021) of which around 900,000 are foreigners and $1,800,000$ are Indians, resulting in drastic social changes and impacts on the land and on the environment. Since decades, the tourism industry has been the most important economic factor for the Leh district contributing more than 50\% of the local GDP and creating employment opportunities and jobs on a large-scale basis in related sectors (Chatterjee et al. 2005, Mir 2014). In fact, it has a short season (May/October) but a highly profitable business especially with domestic visitors increasing by the day. During 2011, around USD 42 million of which 32 million come from Nationals and 10 million from International tourists (Pelliciardi 2013a). According Michaud (1996) the "reliance on external economies, particularly through tourism, has exposed the local economy to fluctuations on a regional and international market' and pose several questions regarding the log-term sustainability of local socio-economic development that strongly depends on mass tourism (Pelliciardi 2012). In general, the growth or falling of tourist arrivals in a specific destination, and the related expansion or crisis of the local tourism industry, are a complex phenomenon and requires multiple pronged approaches to study its various dimensions and considering the sustainability and physical limits of development and related impacts on society (Butler 1980, Dhariwal 2005, Pelliciardi 2016). Yearly arrivals in Leh District depends on several factors and issues like disturbances, national and international terrorism (Dhariwala 2005), global economic crises (Pelliciardi 2016), new tourist destinations (Madhavan \& Rastogi 2011), film induced tourism and the media influx (Angmo \& Dolma 2015, Bhattacharya 2020), weather or climate changes, natural disasters and pandemic (Sharma \& Dolkar 
2020), for instance. However, the factors that influence tourist arrivals are sometimes different between national and international ones (Suresh et al 2015, Kaushik et al 2010) as they have different behaviours, activities and destinations and exert different pressures on the environment and local society (Pelliciardi 2012).

\section{Database and Findings}

This paper, based on data collected from the Tourism Department in Leh (2019) (Diagram 1), analyses the international (I) and national (N) tourist arrivals in time series to find out pattern and trends in the historical data and investigate global and local factors affecting tourist inflows (rises or falls) in the District. In several local administration official documents, national tourists are indicated also as domestics and those international as foreigners; in this paper are consider equivalent and interchangeable designations. Tourist arrivals in Leh District have increased from 500 international and 27 national tourists in 1974 to 327,366 during 2018 (around 50,000 foreigners and 278,000 domestics). The Diagram 1 below depicts the data during the period-considered (47 years, 1974 - 2020). From 1974 to 2007, international tourist arrivals in Leh district predominated on national. During 2008, domestic tourist arrival, for the first time, where more than international (39.000 vs 35.000) indicating the future trend. However, it has since then a come down in the ratio I/N from $95 \%$ in 1990 to $15 \%$ in the 2018 and the related increase of national arrivals from $5 \%$ to $85 \%$.

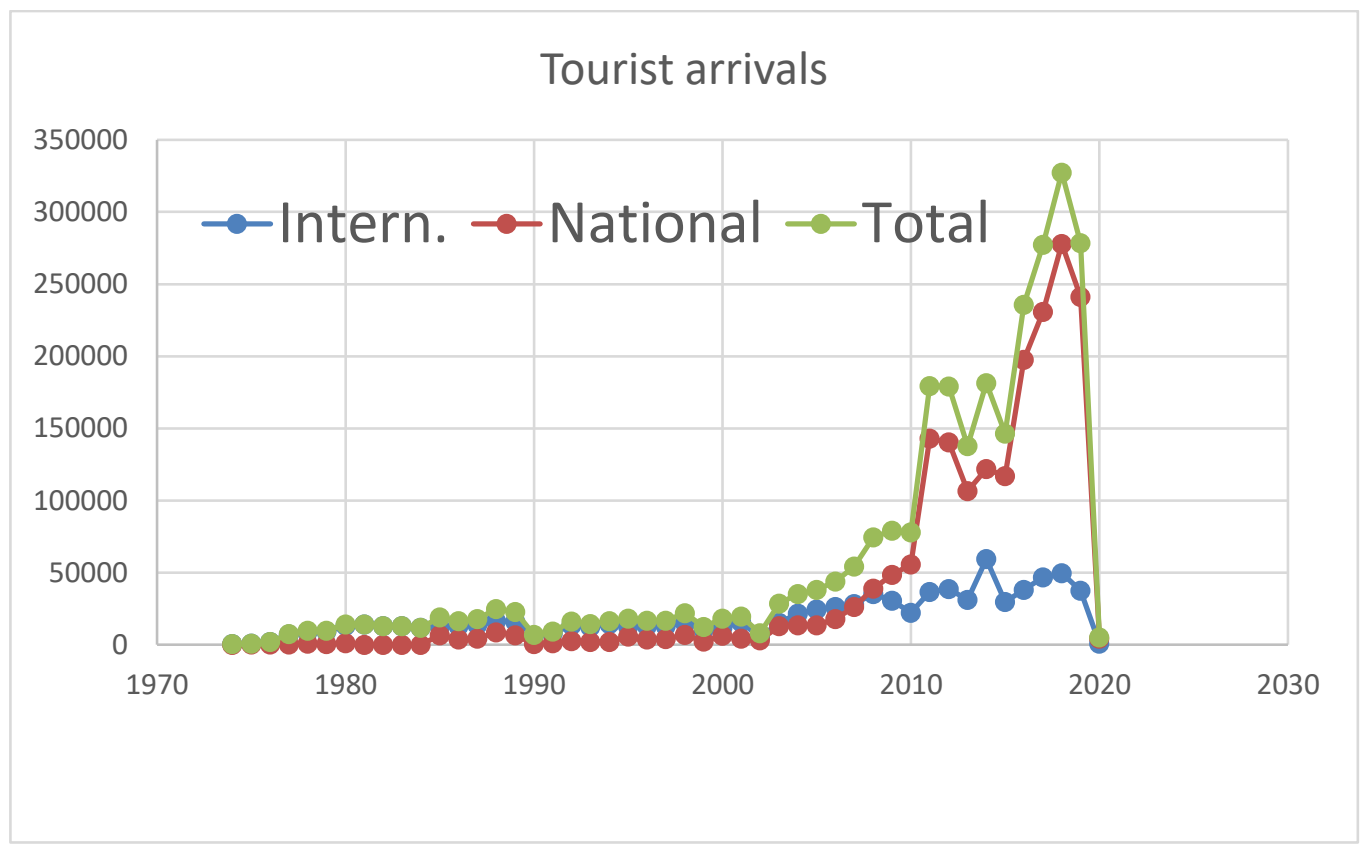

Diagram 1: International, National and Total tourist arrivals in time series (1974-2020). 


\subsection{International tourist arrivals in time series}

In Diagram 2, are the international tourist arrivals by year. A line of constant growth represents the average trend of international flow over the period-considered (1974 - 2020).

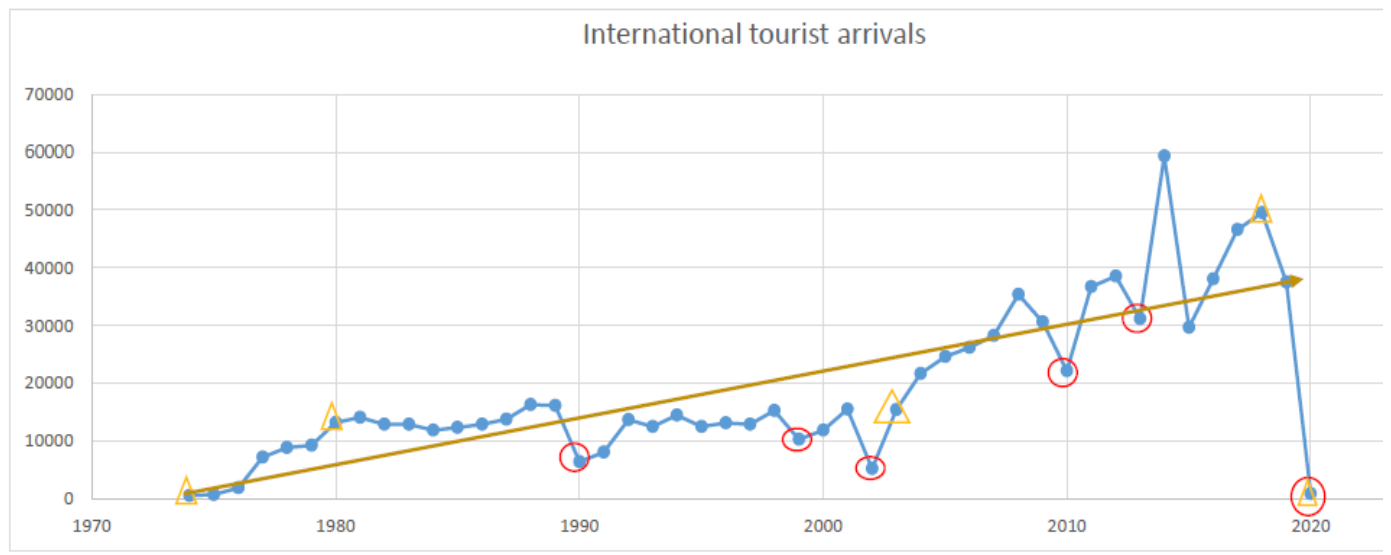

Diagram 2: International tourist arrivals.

Moreover, it is possible to recognize four main period (yellow triangles: from/to), interspersed with years of reductions or even collapses in arrivals (red circle) and sudden peaks or noticeable surges of inflow.

First period 1974 - 1980, constant increment from around 500 up to around 13,300 arrivals.

Second 1981 - 2003, stabilization (with three crisis), oscillating around 13,700 with a peak of 16,200 in 1988 during the Kalachakra ceremony at the presence of the Dalai Lama. Decreasing do to geopolitical turmoil and terrorism crisis:

-1990, minus 60\% (from about 16,100 in the previous year to 6,300) during the political turmoil and street riots of 1989 in Kashmir;

-1999, 33\% less presences (from 15,200 to 10,200) due to the Pakistan-India war;

-2002, 67\% less (from 15,400 to 5,100) due to the attack on Indian parliament, the terrorist act in USA in 2001 September 11, and the threat of Pakistan-India nuclear war.

Third 2004 - 2018, increment (with falls and one high peak) with a consistently upward trend from around 15.300 up to 49.500 :

-2009 foreigner visitors decreased $13 \%$ (5.000 less respect 2008), due to world economic crisis. During 2008, American tourists have decreased from 2,313 (in 2007) down to only 290 (698\% decrease);

-2010, due to the flash flood disaster occurred in Leh valley at the beginning of August (a month which usually acknowledge a good quota of total arrivals, around $30 \%$ on total) which decreased tourist inflows also in the following months;

-2013, occurred a decrease probably due to the high cost of air fares and April Chinese incursion in Changthang; 
-2014, arrivals peaks at 59,000 (21,000 only July, 36\% of the annual total inflow, the highest monthly quota ever recorded) due to the celebration of the $33^{\circ}$ Kalachakra in Leh District during 3-14/July, passing, in 2015, to the same level of arrivals as in 2013.

Fourth 2019 - 2020, reduction, in the first year of the arrivals due to the geopolitical turmoil in Kashmir and finally the total collapse due the covid-19 crisis and word lockdown. In the diagram the figure for 2020 (around 800 visitors) are calculated as a media of international arrivals in January and February during the years 2017/18/19. Moreover, the persistent conflict between India and China along the Changthang, Lhaul, and Spiti Border would certainly have influenced tourist flows by decreasing their presence during the 2020 .

\subsection{National tourist arrivals in time series}

In Diagram 3, are the national tourist arrivals by year. An exponential curve, with a long flat start, well represent the average trend of national arrivals over the periodconsidered (1974-2020). However, 80\% (1,576,000) of total $(\mathrm{N})$ arrivals since 1974 $(1,883,886)$ has arrived only in the last 10 years $2011 / 2020$ vs 37 years 1974/2010.

Diagram 3: National tourist arrivals in time series.

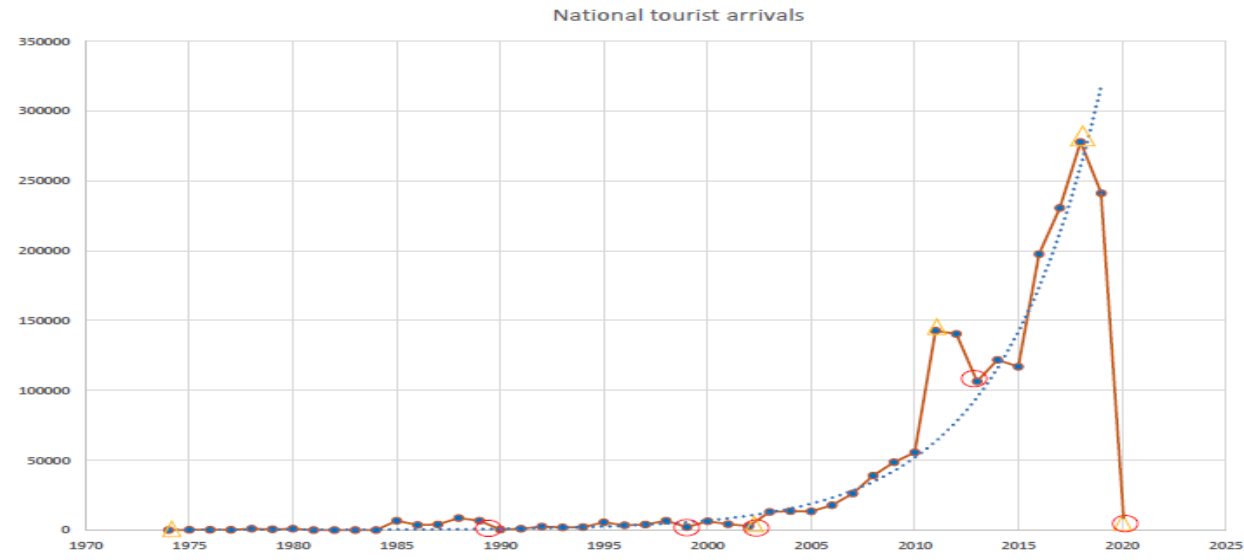

It is possible to recognize three main period (yellow triangles from/to), also containing sudden dips (red circle) or noticeable surges in arrivals.

First period 1974 - 2002, very few national tourist until 1984 and from 1985 to 2002 an average inflow of around 4100 arrivals, with a peak of 8600 presence in 1988. Crisis in the arrivals during 1990 (from around 6700 in the previous year down to 400), 1999 (6800 vs 2100 ) and 2002 (4300 vs 2900) for the same reasons as the falls for international arrivals.

Second 2003 - 2018, constant increment in national arrivals well represented by an exponential curve with percentages of growth in double digits with one peak and fall) -2008, for the first time the nationals overcome the internationals tourists (39.000 vs 35.000) becoming the driving force in the count of total arrivals;

-2011, arrivals soar up to around 143,000 from only 56,000 during 2010 (N/I ratio 2.6). In fact, the release of the Bollywood movie " 3 idiots", where in its storyline has highlighted 
the natural beauty of the District, has had, in accordance of the so called "film induced tourism", a big step upward of domestic tourists;

-2013, a decrease (around 20\%) of the national tourists (with a minimum of 107.000), was probably due to airfare; a return air ticket from Delhi to Leh, 75 minutes journey, reached up to INR 25,000 around $350 €$ per person.

The years 2016, 2017 and 2018 show an exponential growth in the arrivals of Indian tourists, 198,000, 230,000 and 278,000 respectively with ratio between (N)/(I) more than 5 along these three years.

Third 2019-2020, the first year, account a total reduction of visitors respect the previous year due to the geopolitical turmoil in Kashmir highlighted by the figure regarding the tourists arriving to the District by Srinagar road to Leh (from around 95.000 during $2017 / 2018$ down to around 70.000 in 2019).

The reason of the political insurgences was the withdrawal of article 370 of India Constitution (abolition of the autonomous status of the Jammu and Kashmir state and the introduction of the controversial new administrative position of two Union Territories of India: Jammu UT, Kashmir UT and Ladakh UT). Finally the total collapse due the covid19 crisis and India lockdown. In the diagram the figure for 2020 are relative of a media of national arrivals in January and February (around 4400 visitors) during the years 2017/18/19. Moreover, the persistent conflict between India and China along the Changthang, Lhaul, and Spiti Border would certainly have influenced also domestic tourist flows by decreasing their presence during the 2020 .

\section{Discussion}

The demographics of the tourist's inflows in Leh District and the factors influencing arrivals (sometimes different for national and international tourists) have been thoroughly analysed in this study. For the first thirty years, Leh district has been a favourite destination of foreign tourists attracted for its mountainous landscape and environment joy for adventure and sports tourism (short and long trekking in faraway location, rock climbing up to Stok Kangri peak 6,153 metres). Moreover, preferred activities were the Community Based Tourism (staying in beautiful villages nestled in picturesque valleys getting a feel of the folk coupled with practical involvement in the day-to-day chores of the host), the visit to Buddhist heritage sites (monastery and festivals) and attending cultural meetings. A line of constant growth in arrivals well represents the average trend of international inflows over the period considered (1974 - 2020, the highest value took place in 2014 around 60,000) punctuated by sudden drops and peaks in foreign arrivals in specific years. The percentage of international out of total visitors, initially around 95\%, slowly dropped to $60 \%$ in 2004, 48\% in 2008, 20\% in 2015 and 13\% in 2019 due to a rapid increased inflow of domestic visitors. Domestic visitor come in mass to enjoy and admiring particular geo-climatic conditions, cold deserts and glaciers, barren mountains, Indus River and remote lakes. Moreover, they like to visit Leh town, then going, in one day, visiting by car Nubra Valley and Pangong Lake (the so-called "Jeep safari”), and making short visit on tourist spots (in some cases made ad hoc) on the road to preferred destinations and attending Indi festivals like Sindhu Darshan. An exponential curve, with a very long flat start, well represent the average trend of national arrivals over the period-considered 
(1974-2020). Note that $80 \%(1,576,000)$ of the total national tourists in the District $(1,883,886)$ has arrived only in the last 10 years $2011 / 2020$ vs 37 years 1974/2010.

The promotion of tourism industry in the region by Jammu \& Kashmir State and the national India administrations, the "Leave Travel Concession" for travelling by air from Delhi to any destination in J\&K for central government employees, the improved road connections (from Srinagar and from Manali), the better air service (several flights a day), the exuberant Indian economy, giving more travel opportunities to Indian tourist, are among the reasons of this national mass tourism in Leh district. In 2008, the national tourists where more the international (39.000 vs 35.000) becoming the most important driving force in the count of total arrivals. During 2011, the release of the Bollywood movie "3 idiots" (2010), highlighting the natural beauty of Leh district in its storyline, has produced this big step upward due to the so-called "film induced tourism" (Angmo \& Dolma 2015) phenomenon, national travellers grew up to 143,000 from 56,000 while foreigners, in the same year, where only 36,000 such as those in 2008. Then domestic arrivals continued their exponential growth up to an incredible 278,000 in 2018 (more than twice the entire local population) while international travellers reached 50,000 presences. Turbulences for political reason in Kashmir during 2019 decreased the total arrivals (but around 240,000 for domestic and 37,000 international). Regarding the factors and issues influencing yearly arrivals they are sometimes the same sometimes different between $(N)$ and (I) tourists. If crises due to outbreaks in Kashmir, border problems and national and international terrorism (1990, 1999, 2002 and 2019) have reduced flows for both categories (I) and (N), the western world economic crisis during 2008 and 2009 did not affect domestic arrivals, which in fact grew from 39,000 to 49,000. During 2010, natural flood disaster occurred in Leh valley the 6 August, a month that usually acknowledge a good quota of total foreign arrivals (around 30\% on total) decreased the foreign tourist inflows also in the following months; national tourism showed an evident decline in the following months but still growing in total from 49,000 to 56,000 tourists. In 2013, occurred a general decrease of both typology of visitors probably due to the high cost of airfares and April Chinese incursion in Changthang. In 2014, Kalachakra meeting, in the presence of Dalai Lama, was a very popular occasion for more foreign visitors (59,000 vs 31,000 in the previous year). Finally, during 2020, tourism industry collapses due to the covid-19 pandemic crisis and World and India lockdown.

\section{Conclusion}

If the temperature of a body is an indicator of the state of health of the human organism, the time-series of tourist arrivals can give an idea of the changing conditions of the District's anthropic dynamics over the period considered (Pelliciardi \& Pulselli 2021 in press). Modernisation, due to governmental programmes, and the region's progressive opening to external influence and resources characterize the current development path (Morup 2010). Therefore, also the growing mass tourism in the Leh district has strongly influenced local lifestyles, technologies and infrastructures transforming and globalizing District's community in a context of centuries-old indigenous traditions, land use, farming and livestock systems (Dame \& Nüsser 2008, Pelliciardi et al 2014, Ozer \& Schwartz 2016). Massive tourism in Leh district pose several questions and problems. The benefits to the 
economic and monetary level are evident; tourists spend millions of dollars visiting Leh district (Pelliciardi 2013a). The inhabitants of the district have more opportunities for employment (Mir 2014), access to health services, mobility and study opportunities (Gergan 2018). However, distribution of these benefits is unequal: a new rich middle class is formed mostly concentrated in and around Leh town. This power imbalance induce marginalized stakeholders to rural to urban migration (Goodall 2004). Gender inequality is also accounted because men take part in the tourist business while women stay at home with an increased farm workload and immigrant workers (Tarbotton 2000). Anyway, things are changing fast in Leh district and women involvement in the tourism business, administration, army force and local police, health and education sectors, sport and more increasing by decades (Reach Ladakh Bulletin 2019). The growing import of packaged junk food and aerated drinks and other food preferences, imported and subsidized rice instead of locally produced grains, can induce food dependence (Pelliciardi 2013b). A popular "mantra" that I have heard in Ladakh on many occasions (Pelliciardi 2012), with different variations, concerns the loss of the traditional identity and the decline of the community cooperation (Ashton 2001). The progressive commodification of cultural heritage, holding several monastic festivals during the tourist peak season simply accommodate the convenience of tourists and the creation of other so-called pseudo-events (Deboos 2012). Moreover, most of the tourist activities like sightseeing trails, treks and motor rallies, fall in remote, eco-sensitive and protected areas, put many pressure on the environment that represent habitat for several endangered flora and fauna species (Humbert-Droz \& Dawa 2004, Geneletti \& Dawa 2009).

Local administration have to formulate an integrated development plan for a sustainable tourism industry, with the involvement of the community in collaboration with business sector, NGOs and important local associations, to improve quality (perhaps reconsidering the quantity - e.g. the annual tourist arrivals ) trying to minimize the negative impacts on the environment, infrastructure and society and to maximize the positive ones. In contrast with Ladakh's uncontrolled low-cost tourism, Bhutan adopted from the start a policy of "low volume - high yield" tourism, by imposing a substantial daily minimum tariff per international visitor ( $€ 200$ to 250 at present). Until 2016, tourists from India, Bangladesh and Maldives do not pay any tax (they are classified regional non-tariff tourist). During 2015, around 63 percent (98,000 of all arrivals to Bhutan) is constituted of regional nontariff tourists among them, 92 percent were from India. Since few years, District administration in Leh charges all tourists with 420 INR $(400+20$ environmental and wildlife fee, respectively) around 5.5 $€$. In 2017, total 53,000,000 INR $=726,000 €$ has been collected (https://www.leh-ladakh-taxi-booking.com/ladakh-news/tourism-in-leh-needfor-regulation-11-17). Moreover, can be useful to adopt policies to regulating tourist flows in eco-sensitive and protected areas, such as the trekking permit system in force in Nepal and Sikkim - i.e. in Nepal's Mustang Valley - limiting the number of tourist and paying a very high fee. Regarding solid waste and water pollution in these areas, positive examples exist such as the garbage bag deposit system "ifyou bring it in, bring it out" in force in Everest National Park and Mustang in Nepal (Pelliciardi personal experience 2008). To reduce the economic inequality, is necessary to better promote, support and subsidize the Community Based Tourism, the so called Homestay, in house villages and nomadic tents spread on the vast territory to improve the income of the disadvantage families (in Mongolia Tourists 
are guested in the nomadic Yurts, the local tents, Pelliciardi personal experience 2007). In 2016, only 72 Homestays, with around 524-bed capacity are registered in the District against 6008 Hotels and Guest Houses with 12474 beds (https://leh.nic.in/tourism/tourist-info/). Moreover, according the local administration, the construction of five star chains should be generally avoided not only because concentrate the benefits of tourism in a few hands, but because have "to provide their guests with very luxurious living conditions that might impose a severe strain on the fragile eco-system of this region" (LAHDC-L 2005: 25). This study, confirms that tourism industry in Leh district is "complex and non-linear" in accordance to a previous one (Pelliciardi 2016:25). Annual tourist inflows depend from several factors and different issues not under local control (e.g. disturbances, terrorism, economic slowdowns, fleeting nature, tourist habits and new trend destinations) that can occur at unpredictable time and determine the "growth" or the "fall".The system is not very resilient against the factors and issues affecting arrivals and the resulting loss of revenue in case of drastic reductions of visitors. The strong economic and monetary dependence of Leh district on a single sector that of massive tourism, although economically promising but fluctuating, is problematic for the sustainable local development process. Qualitatively oriented further investigations, supported by statistical and numerical analysis on tourist arrivals, can try to assess if, in the near future, Leh district can handle the tourism industry without getting into environmental, economic and social problems that other tourist destinations in India have to face.

\section{References}

Angmo T \& Dolma K. 2015. Mass Media and Film Induced Tourism in Leh District, Jammu and Kashmir, India. International Journal of Science and Research (IJSR). ISSN (Online): 2319-7064, Volume 4 Issue 9 .

Ashton R B. 2001. Development: social disintegration? A study of community change in rural Ladakh. Part II Tripos Dissertation for B.A. Geography, Department of Geography, University of Cambridge, UK. https://www.academia.edu/10182070/Development_Social_disintegration_A_study_of_commu nity_change_in_rural_Ladakh, accessed 02/10/2019.

Bhattacharya S. 2020. After the Tourists Depart: Visual Postmortem of a New Tourist Destination. Journal of Contemporary Archaeology 7.1: 61-78. doi.org/10.1558/jca.37773

Butler R. W. 1980. The concept of a tourist area cycle of evolution: implications for management of resources. Canadian Geographer, 24:5-12.

Chatterjee M, Kohli S, Singh A. 2005. Working Paper No 2, Travel \& Tourism. pg. 5, Center for Development of Corporate Citizenship S. P. Jain Institute of Management \& Research Mumbai.

Dame J \& Nüsser M. 2008. Development perspectives in Ladakh, India. Geographische Rundschau International Edition, vol. 4, no. 4:20-27.

Deboos S. 2012. Tourism promotes the folklorisation process. The case of Kargil and Zanskar festival. In F.Duhart, D.Dias Benavides (eds): Cuerpos y Folklore(s): Herencias, construcciones y performencias, R\&F, Lima, p. 170-181.

Dhariwal R. 2005. Tourist Arrivals in India How important are Domestic Disorders. Tourism Economics. Vol. 11, issue 2:185-205. doi.org/10.5367/0000000054183522.

Geneletti D \& Dawa D. 2009. Environmental impact assessment of mountain tourism in developing regions: A study in Ladakh, Indian Himalaya. Environmental Impact Assessment Review 29:229-242.

Gergan M D. 2018. Life Worlds of Students Studying Outside Ladakh. LAMO - Ladakh Arts and Media Organization, $\operatorname{Vol} 1,5: 3$

Goodall SK. 2004. Rural-to-urban migration and urbanization in Leh, Ladakh. Mountain Research and Development 24:220-227. 
Kaushik N, Kaushik J, Sharma P, Rani S. 2010. Factors Influencing Choice of Tourist Destinations: A Study of North India. IUP Journal of Brand Management, Vol. 7, Issue 1/2:116-132.

Humbert-Droz B \& Dawa S (Eds.). 2004. Biodiversity of Ladakh: Strategy and Action Plan. Sampark, New Delhi.

LAHDC-L (Ladakh Autonomous Hill Development Council of Leh). 2005. Ladakh 2025 Vision Document. http://leh.nic.in/VISION_DOCUMENT.PDF, accessed 10/02/2008.

LAHDC-L. 2018. Statistical Hand Book for the year 2016-17, series 38. Statistics and Evaluation Office, Leh. District Statistical \& Evaluation Agency, Directorate of Economics \& Statistics, Planning \& Development Department, Ladakh Autonomous Hill Development Council, Leh. https://cdn.s3waas.gov.in/s3291597a100aadd814d197af4f4bab3a7/uploads/2018/09/201809072 8.pdf, accessed 10/08/2019.

Madhavan H \& Rastogi R. 2011. Social and psychological factors influencing destination preferences of domestic tourists in India. Journal Leisure Studies Volume 32, 2013 - Issue 2:207-217. doi.org/10.1080/02614367.2011.632781

Michaud J. 1996. A historical account of modern social change in Ladakh (Indian Kashmir) with special attention paid to Tourism. International Journal of Comparative Sociology, 37:286-301.

Mir H A. 2014. Impact of Tourism Industry on Economic Development of Jammu and Kashmir. International Journal of Scientific \& Engineering Research, Volume 5, Issue 6:592-598.

Morup T. 2010. Understanding the transformation in Ladakh. Issues, threats and early warnings. Institute of Peace and Conflict Studies Brief, vol. 151.

Ozer S \& Schwartz S J. 2016. Measuring globalization-based acculturation in Ladakh: Investigating possible advantages of a tridimensional acculturation scale. International Journal of Intercultural Relations. 53:1-15. http://dx.doi.org/10.1016/j.ijintrel.2016.05.002.

Pelliciardi V. 2010. Tourism traffic volumes in Leh District: an overview. Ladakh Studies, 26:14-23.

Pelliciardi V. 2012. Sustainability Perspectives of Development in Leh District (Ladakh, Indian TransHimalaya): an Assessment. Ph.D thesis, La Sapienza University of Rome. Pages 174. http://hdl.handle.net/10805/1738

Pelliciardi V. 2013a. Estimating total receipts for 2011 from Tourism in Leh District. Ladakh Studies 29:6-12.

Pelliciardi V. 2013. From self-sufficiency to dependence on imported food-grain in Leh District (Ladakh, Indian Trans-Himalaya). European Journal of Sustainable Development, 2, 3:109-122. http://www.ecsdev.org/images/V2N3/pelliciardi\%20109-122.pdf.

Pelliciardi V. 2016. Recent trends of tourist arrivals in Leh District (2008-2015): an overview. STAWA, India, 3, 11:24-25.

Pelliciardi V \& Pulselli FM. 2021. Leh district: a trade-off between continuity and changes. An emergy evaluation in time series (1999-2011). In Humbert-Droz B (Ed.) volume: The fast-changing environment of Ladakh: dynamics, challenges \& prospects. International Association of Ladakh Studies Thematic Publication. Springer. Heidelberg. Under press.

Pelliciardi V, Varvaro L and Pulselli FM. 2014. Emergy evaluation of a traditional farming system. Case study: Leh District (Ladakh - Indian Trans-Himalaya). European Journal of Sustainable Development, 3, 4, 1-16. http://ojs.ecsdev.org/index.php/ejsd/article/view/171.

Reach Ladakh Bulletin, Women who made a difference. 2019, Volume 7, Issue 5:1-2, facebook.com/reachladakh/photos/pcb.10156229017718595/10156229010343595, accessed 10/02/2020.

Rizvi J. 1996. Ladakh, Crossroads of High Asia. Oxford India Paperbacks, New Delhi.

Sharma B R \& Dolkar R. 2020. Impact of COVID-19 on Tourism \& Hospitality Sector in Union Territory of Ladakh. In: Managing the Impact of COVID-19 on Financial Services Industry. Publisher: Vidya Kutir Publications, New Delhi, India.

Suresh M, Bid K and Gunasekar S. 2015. Inbound international tourism development in India: A panel data analysis on its affecting factors. IEEE International Conference on Computational Intelligence and Computing Research (ICCIC), Madurai, 2015, pp. 1-4, doi: 10.1109/ICCIC.2015.7435790.

Tarbotton R. 2000. Global Connections, Local Transformations: Women Agriculture and activism in Ladakh. Thesis submitted at University of British Columbia. Unpublished. https://circle.ubc.ca/bitstream/handle/2429/10983/ubc_2000-0593.pdf?sequence=1, accessed $21 / 06 / 2009$.

Tourism Department in Leh. 2019. Datasheet: Tourist Arrival Statement (1974 - 2019). Photocopy unpublished. 